\title{
Competency-based theological education in a postcolonial context: Towards a transformed competency framework
}

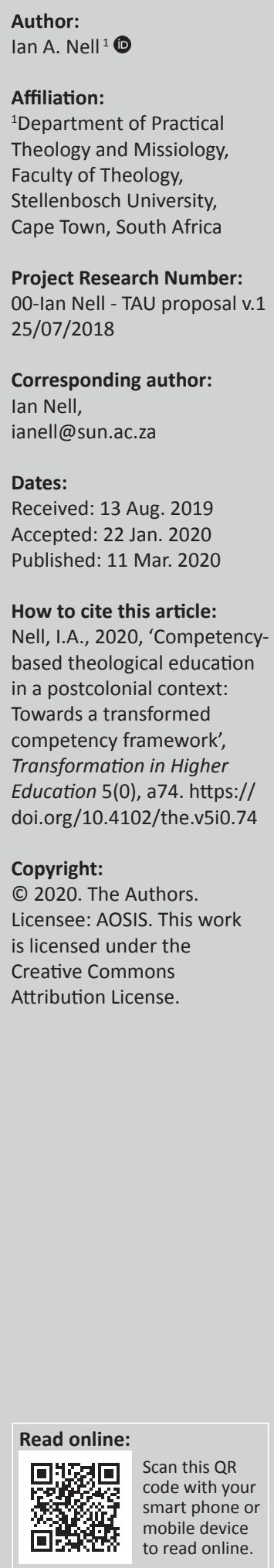

Background: Assessment of students for ministerial practice is traditionally performed through assignments and oral examinations, which often only concentrate on the knowledge component and outcomes of the programme. Assessing students in this way lead to a view of religious practitioners as people who are not really in touch with their parishioners and communicating in language that is not addressing their needs and this normally leads to a disjuncture between knowledge, practice and context. Disjuncture of this nature signals a need for a broader set of competencies than simply working with and analysing texts in theological education.

Aim: The aim of this research is to develop a set of competencies that responds to the reality that the practice of ministry takes place within a rich diversity of postcolonial settings and practices.

Setting: The research was done as part of my own interest in developing a competency framework for religious leaders. I am coordinating the Master of Divinity program as well as the Postgraduate Diploma in Christian Ministry at our Faculty of Theology. Both these programs directly relate to the preparation of students for ministerial leadership.

Methods: The central research question of this study was formulated as follows: What are the central ingredients for developing a competency framework for ministerial formation from a postcolonial perspective at a research-intensive university in South Africa? The method that was used to answer the research question was a literary study of primary and secondary sources related to a broad set of competencies and then narrowing it down to religious leadership as well as some qualitative empirical research in the form of personal interviews.

Results: The research in the article looked at the ways in which a competency framework can help translate generic graduate attributes into a set of competencies that is specific to the field of ministerial training. Some empirical work showed evidence of a growing postcolonial awareness in the development of these competencies.

Conclusion: Through this research a competency framework for religious leaders has successfully been developed. The next phase of the research project will be to implement the framework, to have feedback and to make some adjustments.

Keywords: competency-based theological education; postcolonial context; assessment; competency framework; Master of Divinity.

\section{Introduction}

The overarching question that led to this research was: how well do we prepare our graduates for the 21st century? We have to take the comment of Tencer (2017:2) seriously: 'Eighty five percent of jobs that will exist in 2030 haven't been invented yet'. We therefore have to prepare our students and graduates for a world for which it is essentially not possible to prepare. In preparing our students for these professions that do not yet exist, we have the further responsibility to assess whether they will be in the position to do the work competently.

Therefore, the assessment of students enjoys a high priority in higher education institutions all around the world, and there are also ongoing efforts to improve it by adopting new policies every year. All this is related to quality assurance and control and forms an integral part of the Higher Education Qualification Framework in South Africa. At the Faculty of Theology at Stellenbosch University (SU) (2013), we are currently in the process of going through a new phase of policy renewal in this regard and it forces every lecturer to investigate in depth his or her various forms of assessment. 
Assessment of theology students for ministerial practice is traditionally performed through completing assignments and oral examinations, which often only concentrate on the knowledge component and outcomes of the programme. This has mimicked a view of ministerial practitioners as intellectuals 'preaching over the heads of the congregants and not in touch with the pastoral needs of the members'. This normally leads to a disjuncture between knowledge and practice. This disjuncture signals the need for a broader set of competencies than just working with and analysing texts in ministerial education (Burger \& Nell 2012).

This also responds in part to the reality that the practice of ministry is performed within a rich diversity of postcolonial settings and practices (Naidoo 2012). To resolve this dilemma, a competency framework can help translate generic graduate attributes as well as the profiles of students who finished their studies, as developed by different partner churches, into a set of competencies that is specific to the field of ministerial training.

\section{The involvement of stakeholders}

The need for a competency framework also flows from an initiative from the side of SU in developing four generic graduate attributes, namely, an enquiring mind, an engaged citizen, a dynamic professional and a well-rounded individual. Stellenbosch University has begun the process of embedding the graduate attributes within the curriculum as well as the co-curriculum to ensure that students acquire the core competencies that move them towards graduate success.

The importance of a competency framework has also been recognised by different partner churches at our faculty, for example, by the Uniting Reformed Church, which states in its 'Profile for Ministers of the Word in the Uniting Reformed Church in Southern Africa' (URCSA 2014:13) the following:

- values or attitudes - genuine faith, a sense of calling, selfrespect, character traits, reflexivity, respect for others

- knowledge - basic theological orientation, the Bible or hermeneutics, systematic theology, theological ethics, church history, practical theology, missiology, intercultural theology, ecumenism, church polity and interdisciplinary approach, willingness and ability to use insights from other sciences, global context, general knowledge

- skills - communication skills (proclaiming, teaching, writing), interpretation (hermeneutical) and intellectual skills, spirituality, management or leadership, pastoral caregiving, involvement in society (research, intervention, ecumenical cooperation, community issues).

Before I move on to the problem statement and the research question, it is worthwhile to get some clarity on what is meant by a postcolonial perspective, seeing that this is the context in which this research was performed.

\section{A postcolonial perspective}

Much has been written on what is meant by 'postcolonial,' especially since the student protests and the \#fallist movements came into existence from October 2015 onwards. A number of distinctions have to be made. Postcolonialism, according to scholars Keller, Nausner and Rivera (2004) and Sharp (2012), is primarily concerned with an indication of the time historically following various movements towards independence in the former colonies. In that sense, it is also critical of new forms of colonialism that are ongoing. However, looking at the historical development of colonialism, we see that it is related to the organisation of nations and people in hierarchical relationships of oppression and domination.

A postcolonial perspective could therefore be articulated as narratives that venerate inequalities and hide behind masks of colonising patterns of relationships. A postcolonial perspective therefore emphasises the authenticity of diverse involvement by unmasking the norms that suppress people and limit their possibility for participation. Participation here refers to the purpose of mutuality in relationships between people from diverse structures of interpersonal relationships to institutional and ecclesial structures (Abraham 2008:377).

Postcolonial theories therefore analyse unequal power relations in the era after the formal end of colonialism and focus on the marginalisation and subordination of populations that formerly lived in colonial contexts. According to Sharp (2012:425), '[p]ostcolonial work aims to lessen global oppression and increase justice, particularly in concrete lives of women and children, through recognizing the full humanity of all persons'.

Postcolonial writers such as Fanon (1986) and Mbembe (2001) are interested in culture and identity, gender and race, and with the sustained attention to colonial relations for a better understanding of the coloniser and the colonised. A key vantage point of these postcolonial scholars is to expose the way in which 'common sense' understandings and mainstream scholarship ground the social world in Western perspectives, thereby drawing attention to the epistemological basis of Western power. According to them, these forms of power must be challenged to bring about political change. Mbembe (2001) wrote:

Africa still constitutes one of the metaphors through which the West represents the origins of its own norms, develops a selfimage, and integrates this image into the set of signifiers asserting what is supposed to be its identity. (p. 2)

The postcolonial project is therefore mainly one of critique and derives its strength from its positioning outside of the community responsible for policy-making. In this regard, Fanon's (1986:232) appeal towards the end of Black Skin White Masks could be seen as the apex of many postcolonial writings: 'make of me always a man of questions'.

\section{Problem statement}

It is evident from the argument so far that there is a particular need to develop a competency framework that can be incorporated in the Master of Divinity programme taking the 
postcolonial context into account. This needs to go beyond simply stating the graduate attributes in general terms. There is a need to actively develop students' competencies to function as professional practitioners within this postcolonial context. This includes ways to assess students' competencies in more ways than is traditionally performed.

According to Ashwin (2012), competencies acquired in higher education are assumed to be specific to a field of study and need to be multidimensional. In this sense, these competencies distinguish themselves from intelligence and general cognitive abilities. The Fourth Industrial Revolution, however, will require transdisciplinary approaches to knowledge creation driven by a solution-oriented mindset. This is the case because there is a gradual shift away from higher education as it is traditionally known towards transdisciplinary education.

This is of specific importance for preparing students for ministry. There is also a shift towards programme evaluations based on critical competencies and skills developed, and the related practices. This represents a departure from the emphasis on learning outcomes where knowledge and retention thereof are measured.

\section{Research question}

In the light of the argument above, the research question was formulated as follows: what are the central ingredients for developing a competency framework for a master's degree in theology at a research-intensive university from a postcolonial perspective?

\section{Aims of research}

The aim was to develop, implement and evaluate a first iteration of a competency framework to facilitate the assessment of Master of Divinity students, which could subsequently serve as a framework for the assessment of students more broadly in Master of Divinity programmes in the African postcolonial context. At a broader level, the aim of the project was to challenge the traditional ways of assessment that mostly concentrate only on cognitive (knowledge) skills.

\section{Review of relevant literature}

At SU, from 2015, we started a process of embedding the graduate attributes in the curriculum of certain chosen programmes in the 10 faculties of the university (Nell \& Bosman 2017). This initiative was performed to ensure that students acquire the core competencies that move them towards graduate success. There is in our faculty a particular need to develop a competency framework that can be incorporated into the Master of Divinity programme, in the light of the fact that this is a professional degree required by students who want to go into full-time ministry. This initiative underscored the importance of a framework that goes beyond simply stating graduate attributes in generic terms. A survey of the literature produced the following headings.

\section{From graduate attributes towards competencies}

Research by Jacobs and Strydom (2014) indicated that the development of graduate attributes is enhanced when embedded in a disciplinary framework. In their contribution, entitled 'From "Matie" to Citizen', they look at ways in which graduate attributes as signature learning at SU can help students to become well-rounded individuals and engaged citizens. According to Jones (2013:592), a further determinant of a well-rounded individual is the notion of teaching and learning that embraces life-wide experiences integrated into the textured and complex lives of our students. This takes place by acknowledging the valuable development that occurs in student-driven spaces beyond the classroom and the formal curriculum.

\section{Defining competencies}

There is a voluminous body of literature on competencies, in which competencies are broadly defined as 'a combination of cognitive, affective, motivational, volitional and social dispositions that form the basis for performance' (Shavelson 2010:43). Shavelson presents an approach to measuring and statistically modelling competency measurements by defining competency as a complex ability construct closely related to real-life-situated performance. The intent is to make the construct 'competence' amenable to measurement. Competencies can thus be seen as trait dispositions that are relatively stable over time and across situations, while changes can be induced by dynamic components. An additional consideration for developing a competency framework is Bloom's taxonomy framework, with its emphasis on scaffolding learning. There is a need for threshold concepts to be purposefully integrated into programmes and activities and to make them part of the competency framework.

It is also important to make a distinction between learning outcomes and competencies. Learning outcomes are defined in terms of particular levels of knowledge, skills and abilities that a student has attained (Adam 2008:9). Competencies take this further by describing learning outcomes in terms that define not only what is to be learnt but also the specific levels of performance that students are expected to master (Mulder, Weigel \& Collins 2007:67).

\section{Global competencies}

It is interesting that when one works through the literature, one finds what is called 'global competencies' (Bird, Osland \& Lane 2004:57-80; Jokinen 2005:199-216). According to the Organization for Economic Co-operation and Development Programme for International Student Assessment (OECD PISA) global competence framework (see Figure 1), global competence (Ramos \& Schleischer 2018):

[I]ncludes the acquisition of in-depth knowledge and understanding of global and intercultural issues; the ability to learn from and live with people from diverse backgrounds; and the attitudes and values necessary to interact respectfully with others. Global competence is the capacity to examine local, global and intercultural issues, to understand and appreciate the 


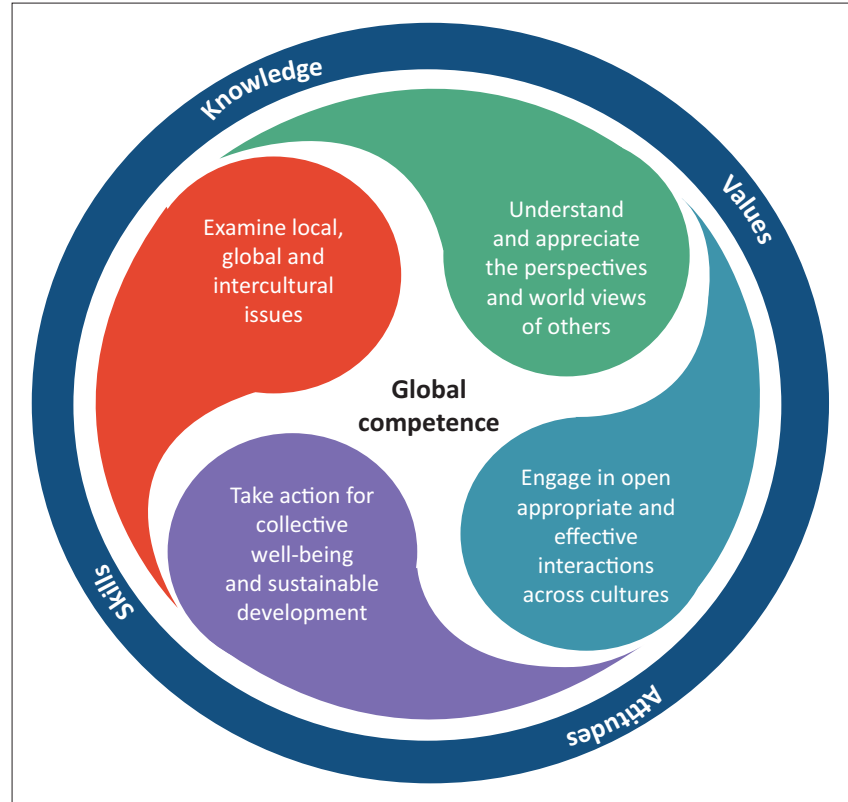

Source: Ramos, G. \& Schleicher, A., 2018, Preparing out youth for and inclusive and sustainable world: The OECD PISA global competence framework, viewed 04 March 2019, from https://www.oecd.org/education/Global-competency-for-an-inclusive-world.pdf

FIGURE 1: The dimensions of global competence.

perspectives and world views of others, to engage in open, appropriate and effective interactions with people from different cultures, and to act for collective well-being and sustainable development. (p. 6)

\section{Increased demand for generic competencies}

An interesting contribution is the work of Young and Chapman (2010), in which they give a description of the historical overview of the development of competency frameworks. According to them, 'rapid transformations of the world economy over the last three decades have precipitated profound changes to labour markets across the globe' (Young \& Chapman 2010:2), and through globalisation a shift away from agriculture or manufacturing towards a new knowledge-based global market took place. This necessarily led to the situation that increased levels of necessity for workers able to keep up with changes that the new economy brought also led to the development of a whole new set of broad skills or generic competencies. They provide interesting examples from all over the globe of the development of these generic competencies.

\section{Competency-based theological education}

The purpose and task of theological training are to educate and equip prospective leaders with the necessary gifts and competencies to empower other believers to participate in the mission of the Church. In this study, the point of departure is that there is a close connection between the quality of theological training and the quality of the candidate arriving for the ministry. Competency-based theological education (CBTE) takes this challenge seriously. According to The Association of Theological Schools (2018), CBTE:

$[R]$ epresents a paradigm shift in theological education. It offers an innovative way for seminaries and learning networks to raise a new generation of proven leaders, trained in context, in the knowledge, in the skills, and in the character traits they need to prosper in their callings. (p. 4)

Compared to the content-transfer model, where the focus is on content and topics of study as the organisational principle, the competency-based model works with fluidity and provides a framework for learning and teaching in a variety of contexts. In the competency model, excellence is mainly measured by the nature of the process and not through knowledge production. The real criterion for excellence in competency-based education is the degree to which the student is ready to function effectively in ministry and show potential for continued theological training (Youngblood 1989:29).

According to Brown (2016), CBTE:

[I]s an educational model that emphasizes: (1) learning more than 'seat time,' (2) the mastery of professionally-oriented competencies, (3) well-planned learning activities or assessments (class-based or not, online or onsite) that students may complete at their own pace, and (4) a community of learning where regular and substantive interaction occurs between qualified faculty and students ... One way to compare and contrast CBTE with more traditional educational models is that the CBTE model holds learning constant while time varies, whereas traditional models hold time constant while learning varies. (p. 2)

From this, it is clear that CBTE is an approach for developing academic programmes where the focus is on the competencies rather than the time spent in classrooms. Students illustrate and demonstrate their skills and knowledge by participating in learning experiences, activities and exercises where there is an alignment with well-defined learning outcomes.

\section{Mwangi and De Klerk (2011) put it as follows:}

As a curricular model, competency-based learning seeks to develop competencies in persons at different stages of their maturation journey. The competencies encompass the development of the whole person: affect understanding, character, and skills. Competency-based learning does not focus on courses and grades but on measuring competencies based on design outcomes. (p. 7)

\section{Research approach: Design-based approach}

The research involved six sequential steps:

- Develop a better understanding of competency frameworks for teaching and learning in higher education based on a literature review.

- Translate those generic competencies and graduate attributes identified in step 1 to the context of ministerial education.

- Engage lecturers (and students) in terms of the need for and experience of making use of the framework. 


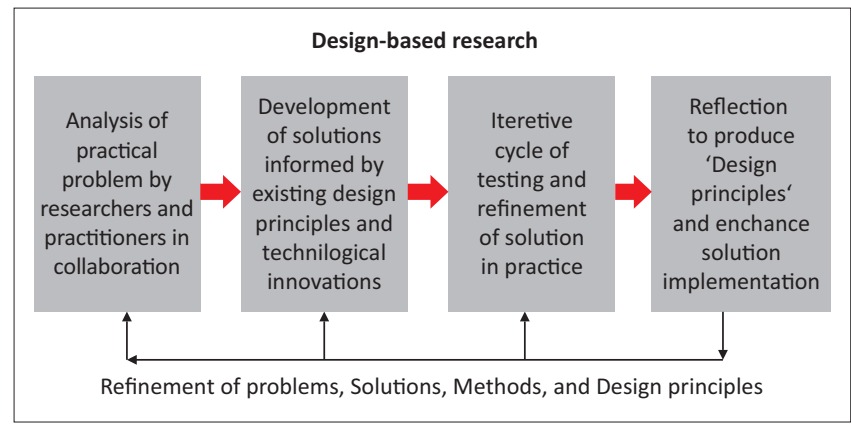

FIGURE 2: Design-based research.

- Design teaching and learning activities for the use of the competency framework in the Master of Divinity programme at SU based on steps 1-3.

- Implement the designed framework.

- Evaluate the implementation in step 5 as the final step of a first cycle of design.

In the six sequential steps, I made use of design-based research as an appropriate research approach to address the research question. The design-based research approach has been succinctly summarised by Reeves (2006) into four phases (see Figure 2).

\section{Phase 1: Analysis of practical problems by researchers and practitioners in collaboration}

The first phase is focussed on the analysis of a significant educational problem, which in this case is the absence of a well-developed competency framework for the Master of Divinity programme. Teachers and researchers together explore the nature of this educational problem facing students. It is also important for teachers to be involved in this phase so that the full extent of the problem is known, rather than being interpreted solely by researchers. A literature review is also conducted in this phase to refer to the work that has already been performed in the area, or in related areas, and how similar problems might have been addressed. After this initial investigation of the problem, related literature and practitioners' ideas, it should be possible to provide draft research questions. By the end of this phase, my aim was to have a clear idea of the problem and its educational context, to have read the literature related to the problem area and to have written preliminary research questions.

\section{Phase 2: Development of solutions informed by existing design principles and technological innovations}

In the second phase, a solution to the problem is proposed that can be implemented in the classroom or educational setting. To create the solution, again, the literature is consulted to find relevant theory that can guide thinking as well as existing design principles that may have addressed a similar problem.

\section{Phase 3: Iterative cycles of testing and refinement of solutions in practice}

Once a learning environment or intervention has been designed and developed (in Phase 2), the next phase of design-based research is the implementation and evaluation of the proposed solution in practice. Design-based research is not a methodology but a research approach. While both qualitative and quantitative methods may be used, it is worth noting that (Van Den Akker et al. 2006):

$[D]$ esign researchers do not emphasize isolated variables. While design researchers do focus on specific objects and processes in specific contexts, they try to study those as integral and meaningful phenomena. (p. 5)

\section{Phase 4: Reflection to produce design principles and enhance solution implementation}

Once a learning environment or intervention has been implemented, evaluated and refined in cycles, the last phase is to produce design principles that can inform future development and implementation decisions.

There are potentially at least three outcomes of design-based research: the design principles, designed products or artefacts - the physical representations of the learning environment (e.g. website, CD-ROM) and societal outputs, such as professional development and learning.

\section{Empirical research: Methodology}

The research design for the empirical research that I used works from an interpretive perspective in qualitative research, with its roots in hermeneutics as the study of the theory and practice of interpretation (Henning, Van Rensburg \& Smit 2004:19-21). The aim of this kind of empirical research is to provide contextually valid descriptions and interpretations of human actions, which are based on an insider's perspective of people and their world. The research was performed by means of a semi-structured interview schedule (five questions) with five of my colleagues from the Faculty of Theology. The following interview schedule was used:

\section{Open ended-interview schedule}

- Tell me about your field of lecturing.

- In relation to what you do, what do competencies mean for you?

- You know about our graduate attributes framework at the university. Do you see a relationship between competencies in our field and the graduate attributes?

- Have you thought about the way in which your field of teaching contributes towards the competencies of the students?

- If you look at the following competencies, which in your opinion are the most important, and how do you rank them?

\section{Interpretation of the data}

In an initial round and to come to an in-depth understanding of what my colleagues understood concerning competencies, I only looked at the answers that my colleagues gave to questions 1 and 2. Looking at the data through these bifocal 
lenses of expertise in lecturing combined with a postcolonial perspective, some interesting data came to the fore.

Concerning the expertise of each of the colleagues, it was interesting to see in what ways it coloured their way of looking at the competencies. Some examples are given as follows:

'So, my field is theology and development, sometimes termed community development, but for me there is a core theological motivation for the church's engagement in issues of poverty and inequality. So, that's the key focus and a lot of my research has been focussed on congregations' response to issues of poverty and inequality across denominations, across race groups.' (Respondent 1 , female, 38 years old)

‘My fields of so-called expertise are called homiletics and liturgy. Homiletics in plain language is all about the art and the act of preaching, and liturgy is all about constructing structures for worshipping God, and both of these two fields of my research [have] to do with communication. It's about the communication of the gospel. So, communication is part and parcel, I would say, actually in the heart of what I try to teach.' (Respondent 2, female, 36 years old)

'I am a lecturer specifically in practical theology and more so, specialisation in youth work, children and faith formation. So, with that, undergrad, I teach modules like Youth Work and Substance Dependency, Children's Ministry and Child Theology. I teach Youth Culture, Planning and Organisation of Youth Work, and I teach Faith Formation.' (Respondent 3, female, 40 years old)

'My sub-discipline in practical theology is pastoral care and counselling. So, I have two undergraduate modules that I focus on. The first one is to give students a basic understanding of the basis or to create a basis for pastoral care and counselling, called the Introduction to Pastoral Care and Counselling, which gives them sort of an overview of what the subject matter entails. And then a specialised module in HIV/AIDS Care in the third year and then on the postgraduate level, I have the opportunity to zoom into more specific areas...' (Respondent 4, male, 52 years old)

'Mine is just much more in the field of theology of religions and that means the religious plurality and the responses of churches, and therefore you get in the second year a kind of an introduction, an overview to religions in Africa and ecumenism or ecumenism and religions in Africa. But then applied or demonstrated in terms of two religions and that would be at least Christianity and African religion or Christianity and African Islam.' (Respondent 5, male, 54 years old)

From the examples above, one can immediately sense that the fields of expertise will have a direct influence on the way the respondents might approach the different competencies. It cannot but colour their perspectives.

Concerning postcolonial perspectives, I found some interesting snippets in the data, for example, the following:

'I think firstly they need to be able to read text and context and the interplay between them. So, for me that's key. They need to have a framework and [...] maybe some normative framework in terms of what theological perspectives relate to issues of poverty and inequality. Also, intercessions of powers are some core frameworks that they need to understand.
But they also need to interpret, to do social analysis and to see how text and context relate to one another and to be able to read that changing context also and how the text relates to it.' (Respondent 1, female, 38 years old)

'If you have good communication linked to real integrity or honesty whatever you want to call that, then you have a moment or moments where communication, deep communication, takes place. You could also, on the other hand, [...] have all the integrity in the world, but if you are lazy and not making use of the best modes of communication that we have also currently, you know, in terms of technology etcetera, etcetera, then you could also sabotage in a certain sense your integrity.' (Respondent 2, female, 36 years old)

'I would think of someone who is able to develop their own theological framework or lens. So, you've studied a degree in theology. So, at some point, I would think you are able to discern and make decisions around what you believe or don't believe based on a lens or framework you've developed while studying. I think that's what makes you different from someone studying theology and someone doing ministry without a theology degree. So, being able to make sound theological choices within ministry based on some form of theoretical framework or lens that you've developed.' (Respondent 3, female, 40 years old)

'My understanding of the competencies is to make sure that the students understand that there are smaller competencies or [that] competencies could be required after one module. But then there are life-long competencies in terms of continuous education, which should always still be part of a student's framework, even while they are busy studying, but also after completion of their studies. That needs to be a reality. The second point is that Pastoral Care and Counselling always works with the existential realities of life, which means that you train young students to deal with the complexities of trauma.' (Respondent 4, male, 52 years old)

'I would say since they engage in a true realistic context [...] they have the appreciative knowledge in terms of cultural and religious diversity. I mean that is the major one. And therefore they should actually as far as the discipline is concerned even begin to map that, depending [on] whether [they are on] the second-year level or the fourth-year level, to map these are the issues that are important because only if you have that kind of knowledge [can] you begin to appreciate the theological and religious and the cultural kind of differences. So, appreciation, it's a key kind of dimension in it also.' (Respondent 5, male, 54 years old)

From the responses, one can see a large number of very different competencies surfaced in the interviews: from competencies to read the text and context, to understanding intercessions of power, to good communication linked to integrity, to developing own theological frameworks, to understanding smaller competencies, to dealing with complexities of trauma and to appreciating knowledge in terms of cultural and religious diversity. When one reads the data through a postcolonial lens, it is obvious that some forms of intersectionality are at play where intersectionality refers to the interaction between race, gender and other classes of differences in social practices, individual lives, cultural ideologies and institutional compositions, and the 
result of these interactions in terms of power (Davis 2008). Respondent 1 , for example, refers to intercessions of power, issues of poverty and doing social analysis sensitising us to postcolonial critiques and generating possibilities for the transformation of the different competencies that deal with these issues. Postcolonial theories can therefore help us deal with structural and material inequalities and force us to ask questions and critique competencies that support sexual, gender, class and race binaries.

\section{Towards a first attempt}

In a first attempt, I linked the four basic SU graduate attributes to four different types of skills: an enquiring mind to personal skills, a well-rounded individual to people skills, an engaged citizen to applied knowledge skills and a dynamic professional to workplace skills. I further developed five different competencies under each of the skills by making use of literature on Master of Divinity programmes, inter alia from the Association of Theological Schools in the United States (see Figure 3).

\section{Assessing the competencies}

Once core competencies required for success in the targeted ministry have been identified, a four-step approach can be set up to help with the improvement of assessing these competencies. It is important to invest the time to write a description, performance standards and indicators for each competency.

- The competency description is a concise, high-level definition of the concept of competency. It expresses the intent and scope of the competency within the context of the programme. It is a necessary element but does not provide enough detail on its own for consistent assessment.

\begin{tabular}{|c|c|c|c|}
\hline \multicolumn{4}{|c|}{ Competency framework for MDiv } \\
\hline Personal skills & People skills & Applied knowledge & Workplace skills \\
\hline Thinking critically & Initiating transformational change & Becoming a mature disciple & $\begin{array}{l}\text { Embracing cultural diversity - cross- } \\
\text { cultural competency }\end{array}$ \\
\hline Research and writing & Exercising flexibility in ministry & Understanding healthy congregations & Articulating biblical theology \\
\hline Practicing biblical hermeneutics & Embodying the love of god & Applying biblical exegesis & Utilising biblical languages \\
\hline $\begin{array}{l}\text { Understanding the development of } \\
\text { doctrine }\end{array}$ & Communicating god's truth & Applying foundational doctrines & Resolving leadership conflict \\
\hline Articulating personal theology & $\begin{array}{l}\text { Recognising one's impact on } \\
\text { other people }\end{array}$ & Embracing sanctification & Taking responsibility \\
\hline
\end{tabular}

MDiv, Master of Divinity.

FIGURE 3: Competency framework for the Master of Divinity.

\section{Competency rubric}

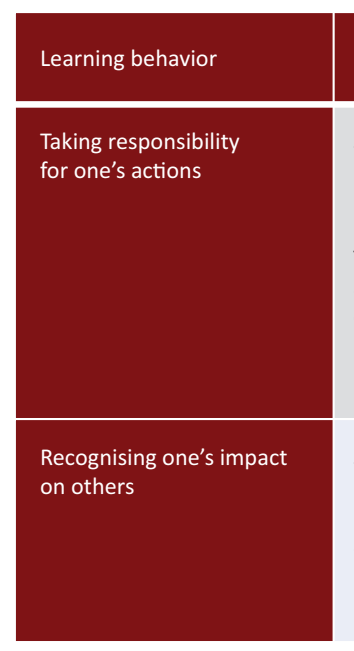

Novice

Student has significant difficulty recognising and articulating a reasonable degree of responsibility. They may deflect much of it or accept much of it without question or critical thought

Student has significant difficulty recognising the impact of their behavior on others. They often attribute undue blame either upon others or themselves.

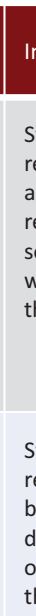

Intermediate

Student has some difficulty recognising and articulating a reasonable degree of responsibility. They may deflect some of it or accept some of it without question or critical thought.
Student has some difficulty recognising the impact of their behavior on others but can describe some impact. They often minimise or exaggerate the seriousness of that impact.

Advanced application
Student has little difficulty
recognising and articulating
a reasonable degree of
responsibility. They do not
deflect much if any and the
responsibility they take is
contextually reasonable and
well-thought out.

Student has little difficulty
recognising the impact of their
behavior on others. They often
attribute reasonable degrees of
responsibility to themselves
and others.

Advanced theory and application

Student has no difficulty recognising and articulating a reasonable degree of responsibility. They demonstrate no deflection at all and demonstrate sound reasoning in terms of distinguishing their degree of responsibility from

others.
Student has no difficulty recognising the impact of their behavior on others. They almost always attribute reasonable degrees of responsibility to themselves and others. 
- Performance standards provide more detail. They describe what mastery of the competency looks like in context; the observable components of the performance that, when combined, fully represent mastery as defined in the description. They articulate what the student is expected to know (cognitive domain), be (affective domain) and do (proficiency domain) with respect to that competency.

- Performance indicators describe observable, measurable behaviours, outputs or circumstances that signal achievement of the performance standards. They quantify criteria a mentor can use to assess whether the student has demonstrated achievement of the performance standard; they describe what evidence of competency achievement might look like in a student.

\section{Conclusion}

In this article, I worked with the basic research question: what are the central ingredients for developing a competency framework for a master's degree in theology at a researchintensive university from a postcolonial perspective? After explaining what I understand under a postcolonial perspective, I reviewed some literature on graduate attributes and competencies and also gave a short description of CBTE. I described my research approach as design-based and gave a short depiction of some empirical research I conducted. The interpretation of the data exposed that the participants revealed their understanding of the competencies from the background of their field of interest, and they defined a number of competencies that they see relevant for theological education. Finally, a first attempt at a competency framework was undertaken, followed by some concluding remarks on the assessment of the different competencies.

\section{Acknowledgements}

This article was delivered at the 14th biennale conference of the International Academy for Practical Theology with the theme '(De)coloniality and religious practices: Liberating hope', 04-08 April 2019, Faculdades EST, Sao Leopoldo, Brazil.

\section{Competing interests}

The author declares that no competing interest exists.

\section{Author's contributions}

I declare that I am the sole author of this research article.

\section{Ethical consideration}

REC Coordinator: Stellenbosch University, Research Ethics Committee: Human Research (Humanities) 7856.

\section{Funding information}

This research received no specific grant from any funding agency in the public, commercial or not-for-profit sectors.

\section{Data availability statement}

Data are available from the author upon reasonable request.

\section{Disclaimer}

The views and opinions expressed in this article are those of the authors and do not necessarily reflect the official policy or position of any affiliated agency of the authors.

\section{References}

Abraham, S., 2008, 'What does Mumbai have to do with Rome? Postcolonial perspectives on globalization and theology', Theological Education 69(2), 376-393. https://doi.org/10.1177/004056390806900208

Adam, S., 2008, 'Learning outcomes current developments in Europe: Update on the issues and applications of learning outcomes associated with the Bologna process,' paper presented at the Bologna Seminar: Learning outcomes based higher education: The Scottish Experience, Edinburgh.

Andrews, R., 2018, Stellenbosch University Co-Curriculum Office: Whole student Experiential Education, Power Point Presentation, Stellenbosch University, Cape Town, South Africa.

Ashwin, P., 2012, Analysing teaching-learning interactions in higher education: Accounting for structure and agency, Continuum, London.

Bird, A., Osland, J.S. \& Lane, H.W., 2004, 'Global competencies: An introduction', in H. Lane et al. (eds.), The Blackwell handbook of global management: A guide to managing complexity, pp. 57-80, John Wiley \& Sons, Hoboken, NJ.

Brown, E.S., 2016, 'Time for a reset' in theological education: 200 gather to discuss innovation at education models and practices forum, viewed 15 November 2019, from https://www.ats.edu/uploads/resources/publications-presentations/ colloquy-online/ed-models-and-practices-forum.pdf

Burger, C. \& Nell, I., 2012, 'Ministerial formation in the Dutch Reformed Churches: In search of new paradigms', in M. Naidoo (eds.), Between the real and the ideal: Ministerial formation in South African Churches, pp. 17-32, Unisa Press, Pretoria.

Davis, K., 2008, 'Intersectionality as buzzword: A sociology of science perspective on what makes a feminist theory successful', Feminist Theory 9(1), 67-85. https:// doi.org/10.1177/1464700108086364

Fanon, F., 1986, Black skin, white masks, Pluto Press, London.

Henning, E., Van Rensburg, W. \& Smit, B., 2004, Finding your way in qualitative research, Van Schaik, Pretoria.

Jacobs, C. \& Strydom, S., 2014, "From "Matie" to citizen: Graduate attributes as signature learning at Stellenbosch University', The Independent Journal of Teaching and Learning 9(1), 63-74.

Jokinen, T., 2005, 'Global leadership competencies: A review and discussion', Journal of European Industrial Training 29(3), 199-216. https://doi.org/10.1108/ 03090590510591085

Jones, A., 2013, 'There is nothing generic about graduate attributes: Unpacking the scope of context', Journal of Further and Higher Education 37(5), 591-605. https://doi.org/10.1080/0309877X.2011.645466

Keller, C., Nausner, M. \& Rivera, M. (eds.), 2004, Postcolonial theologies: Divinity and empire, Chalice Press, St. Louis, MO.

Mbembe, A., 2001, On the postcolony, University of California Press, Berkley, CA.

Mulder, M., Weigel, T. \& Collins, K., 2007, 'The concept of competence in the development of vocational education and training in selected EU member states: A critical analysis', Journal of Vocational Education \& Training 59(1), 67-88. A critical analysis', Journal of Vocational Ed
https://doi.org/10.1080/13636820601145549

Mwangi, J.K., \& De Klerk, B.J., 2011, 'An integrated competency-based training mode for theological training', HTS Theological Studies 67(2), 1-10. https://doi. org/10.4102/hts.v67i2.1036

Naidoo, M. (ed.), 2012, Between the real and the ideal: Ministerial formation in the South African churches, Unisa Press, Pretoria.

Nell, I.A., \& Bosman, J.P., 2017, 'Integrating graduate attributes into a Master of Divinity Programme at a South African University', South African Journal of Higher Education 31(1), 175-190. https://doi.org/10.20853/31-1-868

Ramos, G. \& Schleicher, A., 2018, Preparing out youth for and inclusive and sustainable world: The OECD PISA global competence framework, viewed 04 March 2019, from https://www.oecd.org/education/Global-competency-for-aninclusive-world.pdf

Reeves, T., 2006, 'Design research from a technology perspective', in J.V.D. Akker K. Gravemeijer, S. McKenney \& N. Nieveen (eds.), Educational design research, pp. 64-78, Routledge, Oxford.

Sharp, M.M., 2012, 'Globalizaton, colonialism, and postcolonialism', in B. McLemore (ed.), Wiley-Blackwell companion to practical theology, pp. 422-431, John Wiley \& Sons, Hoboken, NJ.

Shavelson, R.J., 2010, 'On the measurement of competency', Empirical Research in Vocational Education and Training 2(1), 41-63.

Stellenbosch University, 2013, 'Strategy for teaching and learning (2014-2018)', viewed 14 November 2019, from https://www0.sun.ac.za/ctl/wp-content/ uploads/2013/02/SU-STRATEGY-FOR-TL-2014-2018.docx

Tencer, D., 2017, ' $85 \%$ of jobs that will exist in 2030 haven't been invented yet: Dell', HuffPost, viewed 16 November 2019, from https://www.huffingtonpost. $\mathrm{ca} / 2017 / 07 / 14 / 85$-of-jobs-that-will-exist-in-2030-haven-t-been-invented-yetd_a_23030098/ 
The Association of Theological Schools, 2018, Resources, viewed 15 November 2019, from https://www.ats.edu/resources

Uniting Reformed Church in Southern Africa (URCSA), 2014, Manual for Ministerial Formation. Addendum 3: Profile for ministers of the Word in the URCSA viewed n.d., from https://static1.squarespace.com/static/5bb23fabd74562bfe57 $71 \mathrm{ef} 2 / \mathrm{t} / 5 \mathrm{c} 88 \mathrm{c} 54 \mathrm{~b} 4785 \mathrm{~d} 36 \mathrm{da} 4 \mathrm{e} 41072 / 1552467289483 / \mathrm{MF}+$ Manual+2014. pdf
Van den Akker, J., Gravemeijer, K., McKenney, S. \& Nieveen, N. (eds.), 2006, Educational design research, Routledge, Oxford.

Young, J. \& Chapman, E., 2010, 'Generic competency frameworks: A brief historical overview', Education Research and Perspectives 37(1), 1-7.

Youngblood, R.L., 1989, Excellence and renewal goals for the accreditation of theological education, viewed 18 November 2019, from https://philpapers.org/ rec/YOUEAR. 